\title{
Incidence of cancer and mortality among employees in the asbestos cement industry in Denmark
}

\author{
EDITH RAFFN,' ELSEBETH LYNGE, ${ }^{1}$ K JUEL ${ }^{2}$ B KORSGAARD ${ }^{3}$ \\ From the Danish Cancer Society,' Danish Cancer Registry, Institute of Cancer Epidemiology, and Danish \\ Institute for Clinical Epidemiology, ${ }^{2}$ DK-2100 Copenhagen $\varnothing$, and Bedriftssundhedstjenesten, Dansk Eternit- \\ Fabrik Ltd, ${ }^{3}$ DK-9100 Aalborg, Denmark
}

ABSTRACT In a cohort study of the incidence of cancer and mortality among 7996 men and 584ळ women employed in the Danish asbestos cement industry between 1928 and 1984 over $99 \%$ were 3 traced. Chrysotile asbestos was the only fibre type used until 1946, when amosite and (in 1952) $\stackrel{+}{\circ}$ crocidolite were also introduced. Chrysotile constituted $89 \%$, amosite $10 \%$, and crocidolite $1 \%$ of thei asbestos used. During the first 25 years of manufacture the exposure levels were high, especially in $\odot$ areas where the asbestos was handled dry. Measurements from 1948 indicate that the fibre levels may음 have ranged from 100 to 1600 times over the present Danish threshold limit value of $0.5 \mathrm{fibre} / \mathrm{ml}$. In1973 more than $41 \%$ of personal samples were higher than $2 \mathrm{f} / \mathrm{ml}$. About $76 \%$ of the workforce left ${ }_{\mathbb{\Phi}}$ the factory within five years of starting employment. A total of 1346 deaths and 612 cases of cancer을 were observed in the cohort between 1943 and 1984 . Among employed men the overall mortality $\left(\mathrm{O} / \mathrm{E}^{\mathrm{D}}\right.$ $1 \cdot 18 ; 95 \%$ CI $1 \cdot 12-1 \cdot 25)$, cancer mortality $(\mathrm{O} / \mathrm{E} 1 \cdot 32 ; 95 \% \mathrm{CI} 1 \cdot 19-1 \cdot 46)$, and overall incidence of cancer $\left(\mathrm{O} / \mathrm{E} 1 \cdot 22 ; 95 \%\right.$ CI 1.12-1.32) were significantly increased compared with all Danish men. This $\mathscr{\odot}_{\infty}$ was not so among employed women. For men, significant excess risks were found for cancer of the. lung (O/E 1.80; 95\% CI 1.54-2.10), pleura (O/E 5.46; 95\% CI 2.62-10.05), mediastinum (O/E 5.0\%; 95\% CI 1.01-14.61), stomach (O/E 1.43;95\% CI 1.03-1.93), and other male genital organs (O/E 3.08; $95 \%$ CI 1-11-6.60). The mortality was significantly increased for men for non-malignant pulmonary diseases (O/E 1.63; 95\% CI 1.33-1.98). Among the group of asbestos cement workers with first $\frac{\circ}{\mathbb{Q}}$ employment $1928-40$ an excess risk of laryngeal cancer was found $(\mathrm{O} / \mathrm{E} 5 \cdot 50 ; 95 \% \mathrm{CI} 1 \cdot 77-12 \cdot 82)$. $\mathrm{A}_{\rightarrow}$ total of 12 cases of pleural and one of peritoneal mesotheliomas was observed when the originalo notification forms were reviewed for all patients with cancer in the cohort.

In Denmark the manufacture, import, and handling of asbestos and asbestos containing materials have been prohibited by law since 1980 , with the exemption of certain asbestos cement products, brakes, and gaskets.'

Removal of old asbestos materials has to be reported by the employer to the labour inspectorate and the asbestos work has to be planned in such a way that risks to health do not occur. Individuals aged under 18 are prohibited from working with asbestos. Exposure to asbestos should be as low as possible and not exceed the permitted limit of $0.5 \mathrm{fibre} / \mathrm{ml}$. An extension of the exemption for manufacture of asbestos cement products given by the authorities in 1984 started a discussion in Danish society about the continued use of asbestos and the associated health risks. This debate promoted the present follow up of a previous study

Accepted 15 February 1988 of cancer incidence and mortality among employees of Danish Eternit-Fabrik Ltd (DEL) in Aalborg, $\stackrel{\mathbb{D}}{-}$ Denmark. ${ }^{2}$

Since the beginning of this century increasing attention has been paid to the health risks associated with exposure to asbestos fibres. ${ }^{3}$ The major health problems in relation to exposure to asbestos areo asbestosis, lung cancer, and mesothelioma ${ }^{4}$ but cancer? of the larynx,,$^{5-7}$ gastrointestinal tract, ${ }^{8-10}$ and othero sites have also been found to be associated with exposure to asbestos by some investigators in recent 0 years. ${ }^{2-11}$

Although asbestos use is regulated and even prohibited in certain industrial countries the consumption $\omega$ of asbestos in the developing countries is increasing. ${ }^{12}$ Approximately $85 \%$ of the world production of asbestos is being consumed in the asbestos cement industry, primarily used for building materials and pipes. ${ }^{13}$ Chrysotile asbestos is the most often used in 
asbestos cement products.

In recent years a dozen studies of workers in the asbestos cement industry have been published. ${ }^{214-24}$ Most have been mortality studies and the findings for lung cancer have been inconsistent, which has caused a discussion of the risk of lung cancer associated with work in the asbestos cement industry. ${ }^{25}$

In the previous Danish study 6372 men employed from 1944 to 1972 at DEL were followed up for incidence of cancer. Excess risks of cancers of the lung, stomach, larynx, penis, and prostate were observed. ${ }^{2}$ In the present study the incidence of cancer and mortality were followed up for everyone ever employed at DEL between 1928 and 1984.

\section{Material and methods}

\section{FACTORY AND PRODUCTION PROCESS}

In Denmark asbestos cement products have been manufactured in one factory only, DEL, which was founded in the provincial town of Aalborg in northern Jutland in 1927. Production began in 1928 and is still going on. Until 1980 cement was produced within the same plant. In recent years other fibre materials have replaced asbestos and from 1988 all products will be without asbestos.

Figures on the import of raw asbestos into Denmark

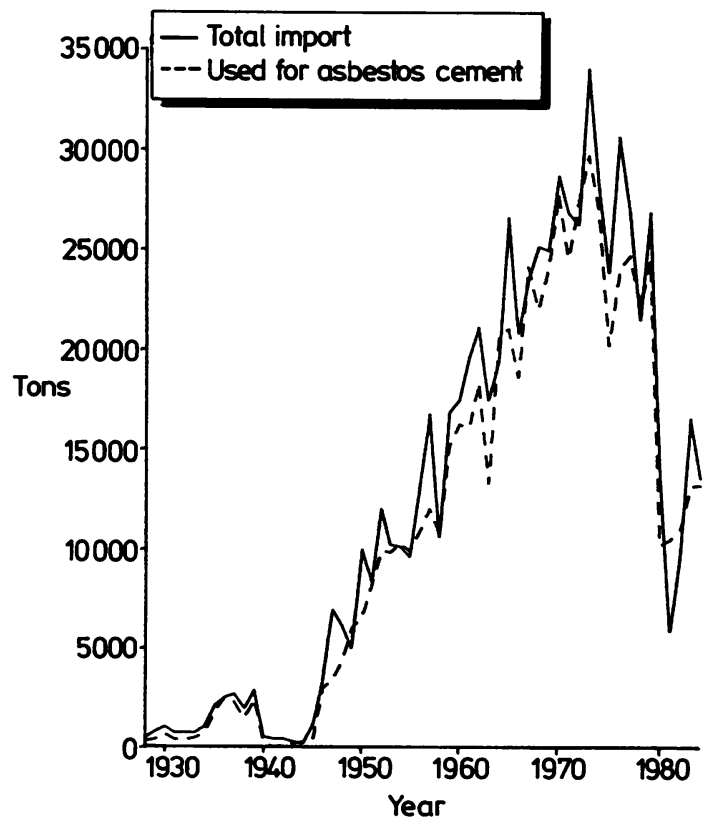

Fig 1 Annual import of raw asbestos into Denmark and consumption of asbestos in manufacture of asbestos cement products. show that nearly $90 \%$ of the total amount has been used in the manufacture of asbestos cement products (fig 1). The main products have been building materials such as corrugated roofings, fittings and mouldings, flat roofing sheets, plates for covering external and internal walls, acoustic sealings, and pipes. The asbestos fibre content in the products have ranged from $5 \%$ to $20 \%$. Chrysotile has been the most frequent type, accounting for $89 \%$ of the asbestos used; smaller quantities of crocidolite $(1 \%)$ and amosite $(10 \%)$ were used for a period after the second world war. During the war, paper replaced asbestos. From 1928 to 1940 only chrysotile asbestos was used. Figure 2 shows the average annual consumption of asbestos at DEL by type of asbestos.

Until 1972 asbestos was delivered in hessian sacks. Before milling, the different types of fibre qualities were mixed together by hand on the floor, rebagged in hessian sacks, and fed by hand into the open asbestos mill. From 1951 water was used in the milling process to reduce the asbestos dust. In 1962 a new mill was introduced in which the asbestos was enclosed during the milling process. Since 1970 improvements in the working environment have been carried out and considerably reduced exposure to asbestos. The hessian sacks have been replaced by plastic bags and many of the other processes have been automated and enclosed.

The first measurements of atmospheric asbestos particles were carried out in 1948 and 1957 and showed that the highest level of particles occurred during feeding the mill and the forming vessel. The Danish National Institute of Occupational Health recently estimated that the exposure levels measured in particles per millilitre in 1948 varied between 50 and $800 \mathrm{f} / \mathrm{ml}$ and in 1957 between 10 and $100 \mathrm{f} / \mathrm{ml}$ (T Schneider, personal communication). Since 1973 quarterly measurements of respirable asbestos fibres based on personal samples have been carried out in the working area. In $197341 \%$ of the exposure measurements were recorded as being above $2 \mathrm{f} / \mathrm{ml}$.

\section{REGISTRATION OF THE COHORT}

In collaboration with DEL, information on all individuals ever employed between 1928 and 1984 by the company was extracted from the personnel file. For workers, records dating back to 1935 were kept in wage books, which provided a specific employment number, name, date of birth, first year of employment, and total wage for each year of employment. From 1 April 1968, the personal identification number was added for each person. The same information was extracted for salaried employees from employment cards also dating back to 1935 .

Until 1942, different employment numbers were used for maintenance workers, asbestos cement work- 


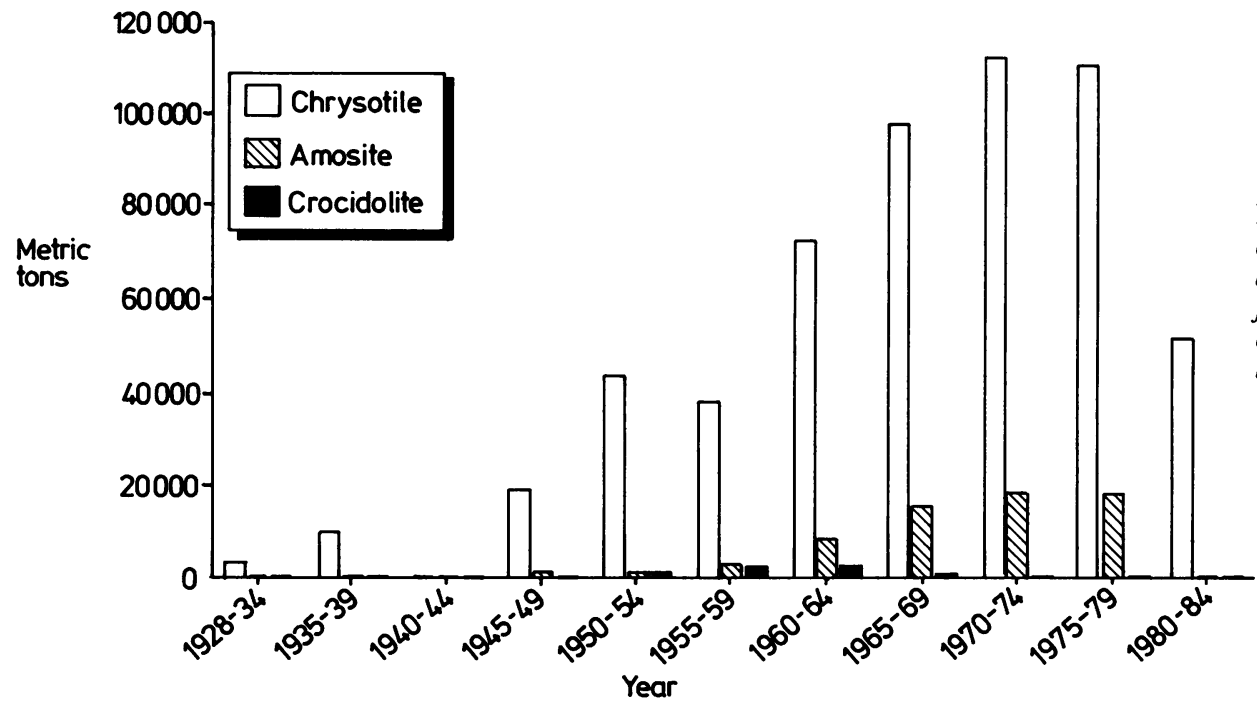

Fig 2 Annual consumption of asbestos in manu- $\vec{T}$ facture of asbestos@ cement products by fibre type.

ers, and cement workers. When a worker left the factory, the same number was reused for a new worker. For most of these employment numbers date of first employment was recorded as 1928 , and it is thus assumed that only $10-15$ workers left the factory between 1928 and 1935, when the use of the wage books began. After 1942 the reuse of employment numbers stopped and continuous numbering was introduced.

By using the information about the employment numbers it is possible to separate the workforce into groups of the salaried employees, maintenance, asbestos cement, and cement workers for those first employed between 1928 and 1942. According to the company, the workers were restricted to their working area in this period, but it is possible that cement workers occasionally worked in the asbestos cement area.

\section{FOLLOW UP FOR DEATH AND EMIGRATION}

In Denmark vital status and date of death or emigration is registered in the Central Population Register (CPR) for everyone who has been living in the country

Table 1 Results of follow up of the cohort employed 192884 at Danish Eternit Ltd

\begin{tabular}{lrcr}
\hline Vital status & Men & Women & Total \\
\hline Alive 31 December 1984 & 6498 & 530 & 7028 \\
Dead before 1943 & 17 & 1 & 18 \\
Dead after 1943 & 1306 & 40 & 1346 \\
Emigrated & 144 & 7 & 151 \\
Disappeared & 5 & 0 & 5 \\
Not identified & 26 & 6 & 32 \\
Total & 7996 & 584 & 8580 \\
\hline
\end{tabular}

since 1 April 1968. The vital status at 31 December $\vec{T}$ 1984 was determined for those in the cohort witho personal identification numbers by a computer based linkage with the CPR. Members of the study popula tion without personal identification numbers were $-\overrightarrow{0}$ traced through municipality population registries, theos Danish Cause of Death Register, and parish registe Table 1 shows the vital status of the study population. Less than $0.5 \%$ could not be identified, and only fore disappeared after initial identification. Those noto identified were excluded from the study.

REGISTRATION OF CANCER AND CAUSES OF DEATH $\overrightarrow{\vec{\sigma}}$ The Danish Cancer Registry contains information on all incident cancer cases diagnosed in Denmark since? 1943. A computerised version of the Danish Cause oP Death Register at the Danish Institute for Clinica $\bar{b}$ Epidemiology contains information on date and cause of death, based on death certificates for all deaths inDenmark since 1943.

The cohort was linked to the computerised file of the Danish Cancer Registry and the Danish Cause of Death Register by the personal identification numberso and for those without personal identification numbers by sex and date of birth, followed by manual check of names. Between 1943 and 1977 cases of cancer werecoded according to a modified version of ICD- $7^{26}$ and since 1978 according to ICD-0. ${ }^{27}$ Causes of death weren coded according to ICD-6, 7, and 8, respectively during the study period. ${ }^{28}$

\section{CALCULATIONS AND STATISTICAL ANALYSIS} For each individual in the study population person years at risk were counted from date of first employment until date of death, emigration, dis- $-\overline{0}$ 
appearing, or the end of follow up on 31 December 1984. All malignant tumours diagnosed during the individual risk periods were included in the analysis.

Expected numbers of cancer cases (E) were calculated using the Monson program, ${ }^{29}$ and based on sex and cause specific cancer incidence rates for five year age groups and five year calendar periods for the total Danish population, 1943-82. Two sided $95 \%$ confidence intervals $(\mathrm{CI})$ for the relative risks $(\mathrm{O} / \mathrm{E})$ were calculated using Byars approximation for the $\chi^{2}$ distribution. ${ }^{30}$ Incidence of cancer among the men for selected diagnoses were calculated by duration of employment and latency time.

The expected numbers of deaths were calculated in the same way as the expected numbers of cases of cancer.

\section{Results}

More than $50 \%$ of the workforce left the factory within one year and $76 \%$ left within five years of starting employment. The number of person-years for men was 146156 and for women 9611. The observed and expected number of deaths among men are given in table 2 by main cause of death. The overall mortality was significantly increased for men $(\mathrm{O} / \mathrm{E} 1 \cdot 18 ; 95 \% \mathrm{CI}$ $1 \cdot 12-1 \cdot 25)$. Malignant tumours caused 359 deaths against 272.44 expected, and non-malignant pulmonary diseases 102 deaths against 62.65 expected. No excess mortality was observed for circulatory diseases. The overall mortality was not increased for women (observed 40, expected 43.90, O/E 0.91; 95\% CI 0.651.24).

Table 3 shows the observed and expected number of incident cases of cancer by site among men. A total of 580 cases of cancer were observed against 477.46 expected, with an $\mathrm{O} / \mathrm{E}$ ratio of $1.22(95 \% \mathrm{CI} 1 \cdot 12$ 1.32). The overall incidence of cancer was not increased among women (observed 32, expected 30.7 ; O/E 1.04; 95\% CI 0.71-1.47).

\section{RESPIRATORY SYSTEM}

Table 3 shows that 192 respiratory tumours were observed in the men; 162 cases of lung cancer were observed against 89.81 expected $(\mathrm{O} / \mathrm{E} 1.80 ; 95 \% \mathrm{CI}$

Table 2 Mortality 1943-84 among men employed at Danish Eternit Ltd 1928-84. No latency time

\begin{tabular}{lrrrl}
\hline Cause of death & \multicolumn{1}{c}{ Obs } & \multicolumn{1}{c}{ Exp } & O/E & $95 \%$ CI \\
\hline All causes of death & 1305 & 1101.82 & 1.18 & $1.12-1.25$ \\
Malignant tumours & 359 & 272.44 & 1.32 & $1.19-1.46$ \\
Non-malignant & & & & \\
pulmonary diseases & 102 & 62.65 & 1.63 & $1.33-1.98$ \\
Circulatory diseases & 489 & 483.50 & 1.01 & $0.92-1.11$ \\
Accidents & 159 & 128.58 & 1.24 & $1.05-1.44$ \\
Other causes & 196 & 154.65 & 1.27 & $1.10-1.46$ \\
\hline
\end{tabular}

Table 3 Incidence of cancer 1943-84 among men* employed 1928-84 at Danish Eternit Ltd. No latency time

\begin{tabular}{|c|c|c|c|c|c|}
\hline Site & $I C D-7$ & Obs & $\operatorname{Exp}$ & $O / E$ & $95 \% C I$ \\
\hline \multicolumn{6}{|l|}{ All malignant } \\
\hline $\begin{array}{l}\text { Buccal cavity, } \\
\text { pharynx } \\
\text { Digestive organs } \\
\text { Stomach } \\
\text { Colon } \\
\text { Rectum } \\
\text { Gallbladder } \\
\text { Respiratory } \\
\text { Larynx }\end{array}$ & $\begin{array}{l}140-148 \\
150-158 \\
151 \\
153 \\
154 \\
155 \cdot 1 \\
160-164 \\
161\end{array}$ & $\begin{array}{r}13 \\
143 \\
43 \\
32 \\
35 \\
6 \\
192 \\
14\end{array}$ & $\begin{array}{r}16 \cdot 44 \\
120 \cdot 96 \\
30 \cdot 09 \\
30 \cdot 16 \\
27.77 \\
3.37 \\
103 \cdot 12 \\
8.44\end{array}$ & $\begin{array}{l}0.79 \\
1.18 \\
1.43 \\
1.06 \\
1.26 \\
1.78 \\
1.86 \\
1.66\end{array}$ & $\begin{array}{l}0.42-1.35 \\
1.00-1.39 \\
1.03-1.93 \\
0.73-1.50 \\
0.88-1.75 \\
0.65-3.88 \\
1.61-2.15 \\
0.91-2.78\end{array}$ \\
\hline Lung & & 2 & & & \\
\hline $\begin{array}{l}\text { Pleura } \\
\text { Mediastinum } \\
\text { Urogenital system } \\
\text { Prostate } \\
\text { Other male }\end{array}$ & $\begin{array}{l}102 \cdot 0,1 \\
162 \cdot 2 \\
164 \\
177-181 \\
177\end{array}$ & $\begin{array}{c}102 \\
10 \dagger \\
3 \\
127 \\
47\end{array}$ & $\begin{array}{r}07.01 \\
1.83 \\
0.60 \\
105.02 \\
34.69\end{array}$ & $\begin{array}{l}5.40 \\
5.00 \\
1.21 \\
1.36\end{array}$ & $\begin{array}{l}2.62-10.05 \\
1.01-14.61 \\
1.01-1.44 \\
0.99-1.80\end{array}$ \\
\hline $\begin{array}{l}\text { Genital } \\
\text { Kidney } \\
\text { Bladder } \\
\text { Skin }\end{array}$ & $\begin{array}{l}179 \cdot 1 \\
180 \\
181 \\
190-191\end{array}$ & $\begin{array}{l}6 \ddagger \\
12 \\
49 \S \\
51\end{array}$ & $\begin{array}{r}1.98 \\
15.39 \\
37.61 \\
72.90\end{array}$ & $\begin{array}{l}3 \cdot 03 \\
0.78 \\
1 \cdot 30 \\
0 \cdot 70\end{array}$ & $\begin{array}{l}1 \cdot 11-6.60 \\
0.40-1.36 \\
0.96-1.72 \\
0.52-0.92\end{array}$ \\
\hline $\begin{array}{l}\text { Brain and nervous } \\
\text { system }\end{array}$ & 193 & 13 & 93 & 2 & (2) \\
\hline $\begin{array}{l}\text { lymphoma } \\
\text { Multiple myeloma } \\
\text { Leukaemia } \\
\text { Other sites }\end{array}$ & $\begin{array}{l}200-202 \\
203 \\
204\end{array}$ & $\begin{array}{r}14 \\
8 \\
9 \\
10\end{array}$ & $\begin{array}{r}15 \cdot 68 \\
4 \cdot 76 \\
13 \cdot 51 \\
28 \cdot 53\end{array}$ & $\begin{array}{l}0.89 \\
1.68 \\
0.67 \\
0.35\end{array}$ & $\begin{array}{l}0.49-1.50 \\
0.72-3.31 \\
0.30-1.27 \\
0.17-0.65\end{array}$ \\
\hline
\end{tabular}

*One man who died and two men who emigrated were excluded on account of the date of first employment registered after death/ emigration.

†All tumours are mesotheliomas.

†All tumours are penile cancers.

$\S$ Papillomas included.

1.54-2 10). Table 4 shows the incidence of lung cancer among men divided into two groups according to duration of employment and with a 15 year latency period. An increased risk of lung cancer was observed in both groups. Table 5 shows the incidence of lung cancer among men by latency time. An increasing trend of the relative risk was seen until the interval 3034 years since first employment (O/E 2.77), followed by a decreasing trend. Table 6 shows the incidence of lung cancer for asbestos cement workers and cement workers with first employment before 1941. A significantly raised risk of lung cancer was found for the asbestos cement workers (O/E 1.88; 95\% CI 1.18$2.85)$ but not for the smaller group of cement workers (O/E 1.2; 95\% CI 0.32-3.07).

Table 3 shows that 10 cases of malignant tumours of the pleura were observed among men against 1.83 expected (O/E 5.46; 95\% CI 2.62-10.05). All tumours were mesotheliomas. Table 4 shows that two of these cases were observed among men employed for less than five years, and eight cases were observed among men employed for five years or more. Table 6 shows that five of these cases were observed among the asbestos cement workers employed before 1941 and no 
Table 4 Incidence of cancer 1943-84 among men* employed 1928-84 at Danish Eternit Ltd by duration of employment with $\overline{\overline{2}}$ 15 years latency time

\begin{tabular}{|c|c|c|c|c|c|c|c|c|}
\hline \multirow[b]{3}{*}{ Cancer site } & \multicolumn{8}{|c|}{ Duration of employment } \\
\hline & \multicolumn{4}{|c|}{$<5$ years $(n=6037)$} & \multicolumn{4}{|c|}{$\geqslant 5$ years $(n=1884)$} \\
\hline & Obs & $\operatorname{Exp}$ & $O / E$ & $95 \% C I$ & $O b s$ & $\operatorname{Exp}$ & $O / E$ & $95 \% C I$ \\
\hline $\begin{array}{l}\text { Lung } \\
\text { Larynx } \\
\text { Pleura } \\
\text { Stomach }\end{array}$ & $\begin{array}{r}45 \\
2 \\
2 \\
13\end{array}$ & $\begin{array}{r}25 \cdot 82 \\
2.46 \\
0.53 \\
7 \cdot 36\end{array}$ & $\begin{array}{l}1 \cdot 74 \\
0.81 \\
3 \cdot 77 \\
1.77\end{array}$ & $\begin{array}{l}1.27-2.33 \\
0.09-2.94 \\
0.42-13.62 \\
0.94-3.02\end{array}$ & $\begin{array}{r}59 \\
6 \\
8 \\
15\end{array}$ & $\begin{array}{r}31 \cdot 13 \\
2.64 \\
0.59 \\
11 \cdot 83\end{array}$ & $\begin{array}{r}1.90 \\
2.27 \\
13 \cdot 56 \\
1.27\end{array}$ & $\begin{array}{l}1.44-2.45 \\
0.83-4.95 \\
5.84-26.72 \\
0.70-2.07\end{array}$ \\
\hline
\end{tabular}

*Excluded are 46 men with long intervals between employment periods.

Table 5 Incidence of lung cancer 1943-84 among men* employed at Danish Eternit Ltd 1928-84 by latency time

\begin{tabular}{lllll}
\hline $\begin{array}{l}\text { Time since first } \\
\text { employment }(y)\end{array}$ & Obs & Exp & O/E & $95 \%$ CI \\
\hline $15-19$ & 21 & $14 \cdot 71$ & 1.43 & $0.88-2 \cdot 18$ \\
$20-24$ & 21 & 12.56 & 1.67 & $1.03-2 \cdot 56$ \\
$25-29$ & 19 & $9 \cdot 50$ & 2.00 & $1 \cdot 20-3 \cdot 12$ \\
$30-34$ & 22 & 7.95 & 2.77 & $1 \cdot 73-4 \cdot 19$ \\
$35-39$ & 10 & $5 \cdot 77$ & 1.73 & $0.83-3.19$ \\
$\geqslant 40$ & 11 & 6.44 & 1.71 & $0.85-3.06$ \\
\hline
\end{tabular}

*Excluded are 46 men with long intervals between employment periods.

cases were observed among the cement workers. When all the original notification forms for patients with cancer in the cohort were reviewed three additional cases of mesothelioma were identified among the men. One case was notified to the cancer registry as lung cancer, one as metastasis in the lung, and one notified case of peritoneal mesothelioma had been coded as an unspecified peritoneal tumour. Table 5 shows that an excess risk of malignant tumours of the mediastinum (O/E 5.00; 95\% CI 1.01-14.61) was found among the men. The risk of laryngeal cancer was not significantly raised among all the men $(\mathrm{O} / \mathrm{E} 1.66 ; 95 \%$ CI $0.91-$ 2.78 ) but table 6 shows a significantly raised risk of laryngeal cancer in the group of asbestos cement workers employed before 1941 (O/E 5.50; $95 \%$ CI 1.77-12.82).

DIGESTIVE ORGANS

Table 3 shows that 143 malignant tumours were observed in the digestive tract in men. The relative risk was significantly raised only for stomach cancer $\left(\mathrm{O} / \mathrm{E}^{\mathbb{D}}\right.$ $1 \cdot 43 ; 95 \%$ CI 1.03-1.93). Table 4 shows that the risk of stomach cancer was slightly higher among men with less than five years' employment than among merto employed for five years or more $\left(\mathrm{O} / \mathrm{E} 1 \cdot 77\right.$ against $\mathrm{O} / \mathrm{E}^{\mathrm{O}}$ 1.27).

\section{UROGENITAL TRACT}

Table 3 shows relative risks at the borderline of statistical significance for prostate cancer $(\mathrm{O} / \mathrm{E} 1 \cdot 36 \stackrel{\mathrm{N}}{\mathrm{N}}$ 95\% CI 0.99-1.80) and for bladder cancer (O/E 1.30\% 95\% CI 0.96-1.72). The risk for other male genitato cancers was significantly raised (O/E $3.03 ; 95 \%$ C $1 \cdot 11-6 \cdot 60)$. All the cases in this group were peringe cancers. The mortality from urogenital cancer was significantly increased.

Among women a non-significantly increased risk for cancer in the genital organs was seen (observed 120 expected 7.86; O/E 1.52; 95\% CI 0.87-2.95); seven were cervical cancers (O/E 1.92; 95\% CI 0.77-3.95).

OTHER SITES

Eight cases of multiple myeloma (O/E $1.68 ; 95 \%$ C $0 \cdot 72-3.31$ ) were observed among the men. No exces risks of lymphoma or leukaemia were found.

\section{Discussion}

The description of working conditions and measurements of fibre concentrations indicate considerable variation in the level of asbestos exposure in

Table 6 Incidence of cancer 1943-84 among asbestos cement workers and cement workers with first employment $1928-40$ at $\mathrm{N}$ Danish Eternit Ltd with 15 years latency

\begin{tabular}{|c|c|c|c|c|c|c|c|c|}
\hline \multirow[b]{2}{*}{ Cancer site } & \multicolumn{4}{|c|}{ Asbestos cement workers $(n=269)$} & \multicolumn{4}{|c|}{ Cement workers $(n=98)$} \\
\hline & Obs & $\operatorname{Exp}$ & $O / E$ & $95 \% C I$ & $O b s$ & $\operatorname{Exp}$ & $O / E$ & $9,5 \% C I$ \\
\hline $\begin{array}{l}\text { Lung } \\
\text { Larynx } \\
\text { Pleura } \\
\text { Stomach }\end{array}$ & $\begin{array}{r}22 \\
5 \\
5 \\
8\end{array}$ & $\begin{array}{r}11.68 \\
0.91 \\
0.21 \\
4.73\end{array}$ & $\begin{array}{r}1.88 \\
5 \cdot 50 \\
23.81 \\
1.69\end{array}$ & $\begin{array}{l}1 \cdot 18-2 \cdot 85 \\
1 \cdot 77-12 \cdot 82 \\
7 \cdot 67-55 \cdot 56 \\
0 \cdot 73-3 \cdot 33\end{array}$ & $\begin{array}{l}4 \\
1 \\
0 \\
3\end{array}$ & $\begin{array}{l}3 \cdot 34 \\
0 \cdot 26 \\
0 \cdot 07 \\
2 \cdot 49\end{array}$ & $\begin{array}{l}1 \cdot 20 \\
3 \cdot 85 \\
-1 \cdot 21\end{array}$ & $\begin{array}{c}0.32-3.07 \\
0.05-21.40 \\
\overline{0} \\
0.24-3.52\end{array}$ \\
\hline
\end{tabular}


different asbestos cement factories. The fibre concentrations in two English factories ${ }^{172}$ and two Swedish factories ${ }^{19} 21$ seem to have been lower than the exposure measured in the Danish factory, where about $40 \%$ of the personal samples in 1973 showed a concentration above $2 \mathrm{f} / \mathrm{ml}$. Differences in cohort size, follow up periods, and inclusion criteria are other possible reasons for the differences found in cancer mortality and incidence of cancer between the asbestos cement studies. In the previous Danish study the overall incidence of cancer was not increased, but an increased incidence appeared when the cohort was followed up for eight more years, and everyone ever working in the factory was included. ${ }^{2}$

\section{RESPIRATORY SYSTEM}

In five of the previous asbestos cement studies the relative risk of lung cancer was significantly raised with a range of the $\mathrm{O} / \mathrm{E}$ ratio from $1 \cdot 34$ to $3 \cdot 87 .^{18-20} 23-24$ The five remaining studies showed relative risks of lung cancer about unity. ${ }^{15-172122}$

In our study 162 cases of lung cancer were observed among men (O/E $1 \cdot 80 ; 95 \%$ CI $1 \cdot 54-2 \cdot 10)$. The relative risk of lung cancer peaks in the $30-34$ years interval after first employment (O/E 2.77), an observation previously described by Selikoff and Lee. ${ }^{3}$ Using employment time as a surrogate for dose, no dose response relation was found for lung cancer. The same phenomenon has been observed for the asbestos cement industries by some other authors, ${ }^{1921}$ although in other studies a linear dose response relation has been shown. ${ }^{4}$ The workforce at DEL has been inhomogeneous concerning exposure to asbestos. Short term employment was frequent among asbestos cement workers. Some were taken in at DEL as storemen late in the spring, when ships with asbestos arrived from Canada, and during the summer as substitutes for the permanent staff. Many did the most dusty work in the production. We know from the early dust measurements that the peak values at some working operations could reach $800 \mathrm{f} / \mathrm{ml}$. Working, for instance, for three months in such a dusty area a high body burden of asbestos fibres must have been accumulated. Short term employees may also have been exposed to other carcinogens during their working career. From other studies of asbestos workers it is known that short term workers belong to a high risk group..$^{21} 31$

Smoking habits among the employees at DEL have never been studied, but a cross sectional study on smoking habits among cement workers in Aalborg in 1973 showed that the prevalence of smoking among cement workers was $3.4 \%$ higher than among men in the city of Aalborg. ${ }^{2}$ This difference in smoking habits is unlikely to explain the increased risk of lung cancer among men employed at the asbestos cement factory.
In three of the previous asbestos cement studies no cases of mesothelioma were specified or observed, ${ }^{151621}$ most mesotheliomas being observed in studies in which an excess risk of lung cancer was found.

In the present study 12 cases of pleural mesothelioma and one case of peritoneal mesothelioma were observed, all in men. Five were observed among the asbestos cement workers with first employment before 1941 and no cases were observed among the cement workers employed at that time. Despite the fact that the factory predominantly used chrysotile asbestos, exposure to amosite and crocidolite cannot be excluded for the cases of mesothelioma. Thus this study does not contribute to knowing whether chrysotile alone in the manufacturing of asbestos cement products may cause mesothelioma in man.

Laryngeal cancer was specified in only four of the previous asbestos cement studies. ${ }^{19212324}$ No cases were observed in the two Swedish studies ${ }^{1921}$ and an observed number of cases below or equals to the expected was found in the other studies. ${ }^{23}{ }^{24}$

In our study a non-significantly raised risk of laryngeal cancer was found for all men (14 (O) $v 8.44$ (E)). The relative risk was significantly raised among the asbestos cement workers employed before 1941 (5 (O) $v 0.91$ (E)). The relatively good survival for patients with laryngeal cancer makes it difficult to detect a possible excess risk in mortality studies. ${ }^{32}$ Differences in exposure levels, fibre types, and qualities could be other reasons for divergent results. Selikoff $e t$ al observed in their study of 17800 asbestos insulation workers a relative risk of 2.34 for laryngeal cancer. ${ }^{8}$ Case-control studies by Stell and McGill ${ }^{5}$ and Shettigara and Mogan $^{6}$ support the evidence for asbestos as a risk factor for laryngeal cancer.

\section{DIGESTIVE ORGANS}

The excess risk of stomach cancer observed in our study corroborates previous findings. ${ }^{18} 192324$ Unskilled workers, who are to some extent over represented in the cohort have an increased risk of stomach cancer in Denmark (E Lynge, personal communication). In a study of stomach cancer and nitrate in the drinking water Jensen found a higher risk in the city of Aalborg than in other Danish provincial towns. ${ }^{33}$ No significant excess risks for other malignancies of the digestive tract were seen in our study.

\section{OTHER SITES}

Excess risks for prostate and penile cancer had been observed already in the previous study by Clemmesen and Hjalgrim-Jensen. ${ }^{2}$ All the penile cancers were carcinomas of prepuce or glans. A hypothetical explanation for the finding could be that asbestos fibres interact with other risk factors such as phimosis. As for laryngeal cancer, an excess risk of penile cancer 
is difficult to show in mortality studies due to the relatively high survival rate for these patients. Thus the mortality of urogenital cancer was not increased in our study.

No excess risk of lymphomas was found, but a nonsignificantly raised risk of multiple myeloma is in line with a suggested association with asbestos. ${ }^{34}$

Eva Valente and Thorbj $\phi r n$ S $\phi$ rensen helped with the data collection. Niels Christensen and Gerda Engholm provided data processing help and Annie Fosselius prepared the manuscript.

Requests for reprints to: Dr E Raffn, Danish Cancer Society, Danish Cancer Registry, Institute of Cancer Epidemiology, Landskronagade 66, DK 2100 Copenhagen $\varphi$.

\section{References}

1 Departmental order of the Ministry of Labour on asbestos. 1979. (In Danish.)

2 Clemmesen J, Hjalgrim-Jensen S. Cancer incidence among 5686 asbestos-cement workers followed from 1943 through 1976. Ecotoxicol Environ Safety 1981;5:15-23.

3 Selikoff IJ, Lee DHK. Asbestos and disease. New York: Academic Press, 1978.

4 Acheson ED, Gardner MJ. Asbestos. The control limit for asbestos. (Health and Safety Commission.) London: HMSO, 1983.

5 Stell PM, McGill T. Asbestos and laryngeal carcinoma. Lancet 1973;ii:416-7.

6 Shettigara PT, Morgan RW. Asbestos, smoking and laryngeal carcinoma. Arch Environ Health 1975;30:517-9.

7 Rothman KI, Cann CI, Flanders D, Fried MP. Epidemiology of laryngeal cancer. Epidemiol Rev 1980;2:195-209.

8 Selikoff IJ, Hammond EC, Seidman H. Mortality experience of asbestos insulation workers in the United States and Canada, 1943. Ann NY Acad Sci 1979;330:91-116.

9 Miller AB. Asbestos fibre dust and gastro-intestinal malignancies. Review of literature with regard to a cause/effect relationship. $J$ Chronic Dis 1978;31:23-33.

10 Morgan RW, Foliart DE, Wong O. Asbestos and gastrointestinal cancer-a review of the literature. West J Med 1985;143:60-5.

11 Ross R, Dworsky R, Nichols P, et al. Asbestos exposures and lymphomas of the gastrointestinal tract and oral cavity. Lancet 1982;ii:1118-9.

12 Asbestos Institute. Favorable growth prospects for asbestos in Asia. Asbestos 1985:I:4-5.

13 Royal Commission on Matters of Health and Safety Arising from Use of Asbestos in Ontario. Report. Ottawa: Ontario Ministry of the Attorney General, 1984.
14 Weill $\mathrm{H}$, Hughes J, Waggenspack $\mathrm{C}$. Influence of dose and fiber type on respiratory malignancy risk in asbestos-cement marut facturing. Am Rev Respir Dis 1979;120:345-54.

15 Haider $M$, Neuberger $M$. Comparison of lung cancer risks for $d$ workers, asbestos-cement workers and control groups. In: Wagner JC, ed. Biological effects of mineral fibres. Lyon: IARE, 1980:973-7.

16 Lacquet LM, von der Linden L. Roentgenographic lung changes, asbestosis and mortality in a Belgian asbestos-cement factogy. In: Wagner JC, ed. Biological effects of mineral fibres. Lyøa: IARC, 1980: 783-93.

17 Thomas HF, Benjamin IT, Elwood PC, Sweetnam PM. Further follow-up study of workers from an asbestos-cement factory. $\$$ $J$ Ind Med 1982;39:273-6.

18 Finkenstein MM. Mortality among employees of an Ontarid asbestos-cement factory. Am Rev Respir Dis 1984;129:754-61.

19 Albin M, Jacobsen K, Englander V, et al. Mortality and can $\overrightarrow{e g r}$ morbidity in a cohort of asbestos cement workers. Lurp: Yrkesmedicinska kliniken, 1984. (In Swedish.)

20 Alies-Patin AM, Valleron AJ. Mortality of workers in a Frencin asbestos-cement factory 1940-82. Br J Ind Med 1985;42:219-25.

21 Ohlson CG, Hogstedt C. Lung cancer among asbestos-cement workers. A Swedish cohort study and a review. Br J Ind Med 1985;42:397-402.

22 Gardner MJ, Winter PD, Pannett B, Bowell CA. A follow up stugy of workers manufacturing chrysotile asbestos-cement products. Br J Ind Med 1986;43:726-32.

23 Hughes JM, Weill H, Hammed YY. Mortality of workers employed in two asbestos-cement manufacturing plants. $B \mathrm{QJ}^{\mathrm{J}}$ Ind Med 1987;44:161-74.

24 Enterline PE, Hartley J, Henderson V. Asbestos and cancer尺्र్a cohort follow up to date. $\mathrm{Br}$ J Ind Med 1987;44:396-401.

25 Gardner MJ, Powell CA. Mortality of asbestos cement workg using almost exclusively chrysotile fibre. J Soc Occup 1986;36:124-6.

26 Clemmesen J. Statistical studies in the aetiology of maknam neoplasms. I. Review and results. Acta Pathol Microbiol sicomd 1977; suppl.

27 World Health Organisation. ICD-O. International classification $f$ oncology. Geneva: WHO, 1976.

28 Danish National Board of Health. Classification of diseaser. Copenhagen: DNBH, 1976. (In Danish.)

29 Monson RR. Analyses of relative survival and proportio mortality. Computers and Biomedical Research 1974;7:325-39

30 Breslow NE, Day NE. The standardized mortality ratio. In: Sen PK ed. Biostatistics: statistics in biomedical, public health agdd environmental sciences. North-Holland: Elsevier, 1985.

31 Seidman H, Selikoff IJ, Hammond EC. Short-term asbestos wowk exposure and long-term observation. Ann NY Acad \&ु 1979;330:61-89.

32 Doll R, Peto J. Asbestos. Effects on health of exposure to asbesto. (Health and Safety Commission.) London: HMSO, 1985.

33 Jensen $O M$. Nitrate in drinking water and cancer in northe्nn Jutland, Denmark, with special reference to stomach cancer. Ecotoxicol Environ Safety 1982;6:258-67.

34 Kogan E, Jacobson RJ, Yeung KY, et al. Asbestos associatod neoplasms of B cell lineage. Am J Med 1979;67:325-30. 